\title{
Outcome measures following Sono and Photodynamic Therapy - A Case Series
}

\author{
Julian N. Kenyon ${ }^{1 *}$ \\ 'The Dove Clinic, Twyford, Winchester, Hampshire, SO2 1 1NT, England.
}

\section{Article Info}

\section{Article Notes}

Received: February 16, 2021

Accepted: March 09, 2021

\section{${ }^{*}$ Correspondence:}

Dr. Julian N. Kenyon, The Dove Clinic, Twyford, Winchester, Hampshire, SO21 1NT, England; Telephone No: 01962 718000; Mobile No: 07740786342; E-mail: jnkenyon@doveclinic.com

C 2021 Kenyon JN. This article is distributed under the terms of the Creative Commons Attribution 4.0 International License.

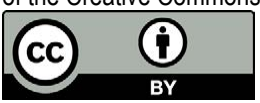

Keywords:

Sono and Photodynamic Therapy

Case series

\begin{abstract}
Sono and Photodynamic Therapy (SPDT) is a novel therapeutic modality that utilises a non-toxic photosensitive agent with reported ultrasoundactivated properties. SPDT has previously demonstrated significant tumour cell inhibition in animal studies. There has been much research into the efficacy of photodynamic therapy and development in understanding of the underlying mechanism of tumour cytotoxicity. Synergistic ultrasound activation represents a promising development to Photodynamic Therapy, as photo-activation is limited by access and penetrance issues. Ultrasound has been demonstrated to activate a number of sono-sensitive agents allowing the possibility of noninvasive targeted treatment of deeper tumour sites than is currently achievable with photodynamic therapy. This case series of 17 consecutive patients with a variety of cancer diagnoses outlines clinical outcomes over a four-year period of SPDT. The results have been encouraging in that all cases who carried our Circulating Tumour Cell Tests before and after SPDT showed a significant drop in tumour cells post-SPDT. SPDT is worthy of further investigation as an effective and well tolerated treatment for a wide variety of primary and metastatic tumours, including those refractory to Chemotherapy.
\end{abstract}

\section{Introduction}

A case series of 17 consecutive patients with a variety of Cancer diagnoses outlines clinical outcomes over a four-year period of Sono and Photodynamic Therapy (SPDT).

This is a novel therapeutic modality that utilises a nontoxic photosensitive agent with reported ultrasound-activated properties. This treatment centres around the development of a specific light and ultrasound activated sensitiser (Sonnelux1) which has previously demonstrated tumour cell inhibition in animal studies and provides a new method of inducing targeted tumour cell necrosis. Many of the patients included in this case series have advanced metastatic cancer diagnoses, and most have failed to respond to conventional management approaches. We have previously published in this area $^{1,2}$ Many of these cases showed significant extension of predicted median survival and also of outcome measures as measured by Circulating Tumour Cell Tests ${ }^{3}$. Other Authors have demonstrated significant results using SPDT $^{4-6}$.

\section{Background}

\section{Photodynamic Therapy - Light Activated Therapy}

Photodynamic Therapy (PDT) is an established therapeutic option for a variety of pre-cancerous and malignant pathologies. The majority of PDT photosensitive agents possess a heterocyclic ring structure similar to that of chlorophyll 
or the haem group in haemoglobin that can be administered via topical or systemic routes. The photosensitiser becomes activated by light energy applied from an LED or coherent laser emission source. Following absorption of light at a specific wavelength by the photosensitiser, a transfer and translation occurs of light energy into a chemical reaction. In the presence of molecular oxygen this produces singlet oxygen $\left(\begin{array}{ll}1 & 02\end{array}\right)$ or superoxide (02 -), and induces cell damage through direct and indirect cytotoxicity ${ }^{7}$. A variety of photosensitisers demonstrates elective absorption into malignant cells, increasing the potential to target cytotoxicity ${ }^{7,8}$ and limit unwanted side-effects.

Photo-activation is however limited to surface pathology, or tumour mass capable of being targeted via endoscopic access. This is due to absorption of light into surrounding tissue, which creates limitation on penetrance and the depth of photosensitiser activation. The use of new photosensitisers sensitive to longer wavelengths of light increases depth of penetration ${ }^{7}$, but effective non-invasive treatment of deep tumour sites remains problematic.

\section{Sonodynamic Therapy - Ultrasound Activated Therapy}

Ultrasound is a mechanical wave with periodic vibrations of particles in a continuous, elastic medium at frequencies equal to or greater than $20 \mathrm{kHz}$. It is not only perceived as safe, but has excellent tissue penetrating ability without major attenuation of its energy ${ }^{8,9}$. Therefore, the potential medical application of ultrasound has been evaluated extensively and has led to the routine use of ultrasound for diagnostic imaging of soft tissue ${ }^{9}$.

Ultrasound Activated therapy (sonodynamic therapy), the ultrasound dependent enhancement of cytotoxic activities of certain compounds (sonosensitisers), is an attractive modality for cancer treatment with potential to focus the ultrasound energy on tumour sites buried deep in tissues and to locally activate a preloaded sonosensitiser. The effect can be localised by focusing the ultrasound on a defined region and choosing compounds with tumour affinity ${ }^{10,11,12,13}$, causing enhanced cytotoxicity at pathological sites with minimal damage to peripheral healthy tissue. Potentiated cytotoxicity by ultrasound was first demonstrated when mouse leukaemia L 1210 cells were exposed to continuous wave ultrasound ( $2 \mathrm{M} \mathrm{Hz}, 10 \mathrm{~W} / \mathrm{cm} 2)$ while suspended in nitrogen mustard solution in vitro. Mice subsequently inoculated with these cells had longer survival times than control animals that received cells exposed to the drug but not ultrasound ${ }^{14}$.

Following this, theapplication of low-levelultrasound toa biological target was found to potentiate chemotherapeutic cell killing with adriamycin and diaziquone ${ }^{15}$. In vivo, this combined drug and ultrasound treatment resulted in statistically significant reductions in tumour volume of uterine cervical squamous cell carcinoma implanted in the cheek pouch of the Syrian hamster compared to the chemotherapeutic alone. The ultrasound applied without the chemotherapy agent was non-cytotoxic and produced negligible temperature elevation. The photodynamic sensitisers have also been studied for ultrasound-activated properties. They have the benefit of being non-toxic unless activated and have been demonstrated to have tumour localizing properties. Hematoporphyrin, a commonly used photo-sensitiser enhanced the killing of mouse sarcoma and rat ascites 130 tumour cells exposed in vitro to ultrasound $(1.92 \mathrm{MHz})$ at intensities of 1.27 and 3.18 $\mathrm{w} / \mathrm{cm} 2$, from $30 \%$ and $50 \%$ to $99 \%$ to $95 \%$ respectively [16]. Possible cytotoxic mechanisms include generation of sonosensitiser-derived radicals which initiate chain peroxidation of membrane lipids via peroxyl and/or alkoxyl radicals, the physical de stabilization of the cell membrane by the sonosensitizer thereby rendering the cell more susceptible to shear forces and cavitation effects or ultrasound enhanced drug transport across the cell membrane (sonoporation) ${ }^{13,17,18}$.

\section{Sonnelux-1 - A Dual Activation Agent}

Light and Ultrasound Activation Sonnelux-1 is a metallochlorin complex, containing a highly purified mixture of several chlorophyllins, each with a different side chain and an average molecular weight of 942 . Sonnelux-1 has photo-activation properties and has also been demonstrated to be extremely sensitive to ultrasound $^{16}$. Safety studies, including LC50 studies of $S$ onnelux- 1 as determined in zebrafish, reveal that Sonnelux-1 is essentially non-toxic. No zebrafish death is noted at the maximum soluble concentration of the sonosensitiser (data pending publication). 7 Sonnelux-1 is registered as non-hazardous according to OSHA standards and EU directives.

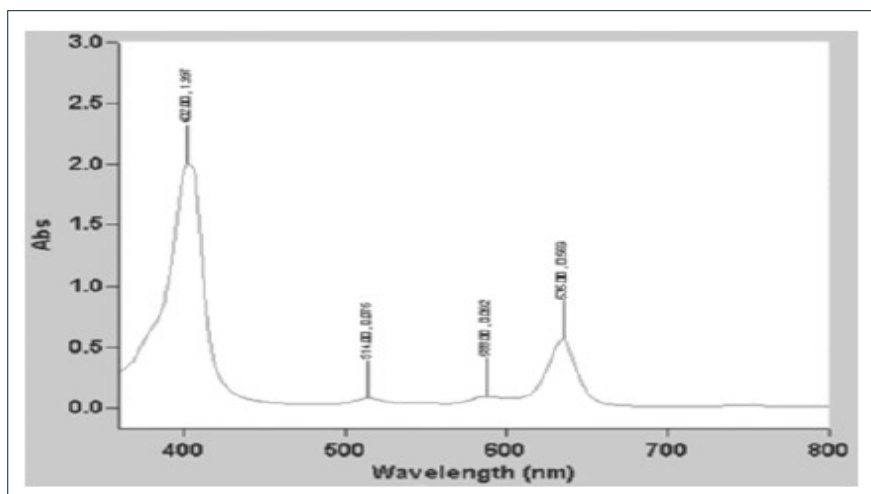

Figure (1): A graph to show light absorption by Sonnelux-1 by specific wavelength (Sonnelux-1 diluted 1:1000).Absorption scan, "Chem Lab" instrument. 


\section{Sonnelux-1 Animal Studies Demonstrating Dose Dependent Ultrasound Activated Tumour Cytotoxicity}

Sonnelux-1 has demonstrated significant tumour cell cytotoxicity following ultrasound-activation using a mouse S-180 Sarcoma model ${ }^{20}$. Following treatment, tumour volume was monitored. Significant tumour growth inhibition was seen in the group that was administered both ultrasound and Sonnelux-1 with significant $(\mathrm{p}<0.01)$ reduction in mean tumour we might (see Fig. 2). No significant difference occurred with ultrasound or Sonnelux administration alone.

Significantly, cytotoxicity increased in a dose-dependent manner from $0.3 \mathrm{~W} / \mathrm{cm} 2$ to $1.2 \mathrm{~W} / \mathrm{cm} 2$ (see Fig. 3 and Fig. 4). Histology showed coagulated necrosis or metamorphic tissue which started within 2 hours of ultrasound activation ${ }^{20}$. Tumour cytotoxicity was also reported when a

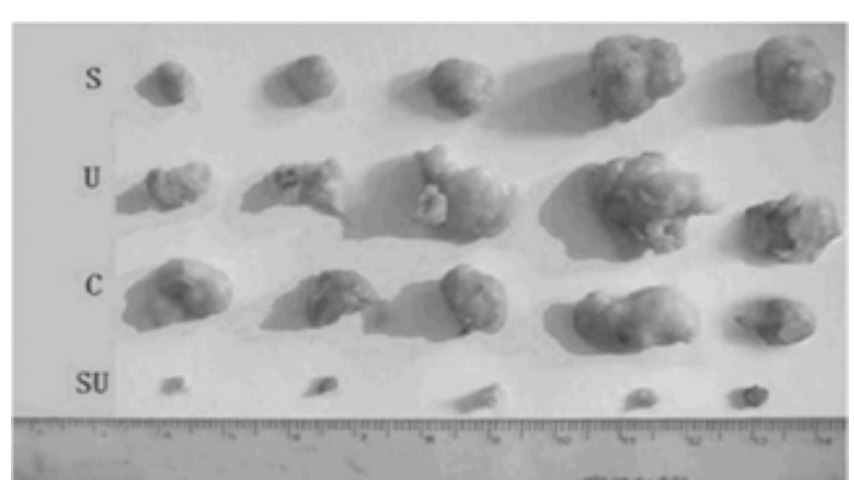

Figure (2): Photographs of mouse S-180 tumours peeled off 15 days after treatment from each group of mice, showing significant reduction in tumour volume after combined sonnelux-1 and ultrasound administration i $\mathrm{n}$ a light tight room. Top line (S) Sonnelux-1 treatment without ultrasound or light exposure. Second line (U) - ultrasound 1. $2 \mathrm{~W} / \mathrm{cm} 2$ without Sonnelux-1 administration. Third line (C) - Control sample without ultrasound or Sonnelux-1 administration. Fourth line (SU ) - Sonnelux 1 treatment plus ultrasound $1.2 \mathrm{~W} / \mathrm{cm} 2$ in a light tight room.

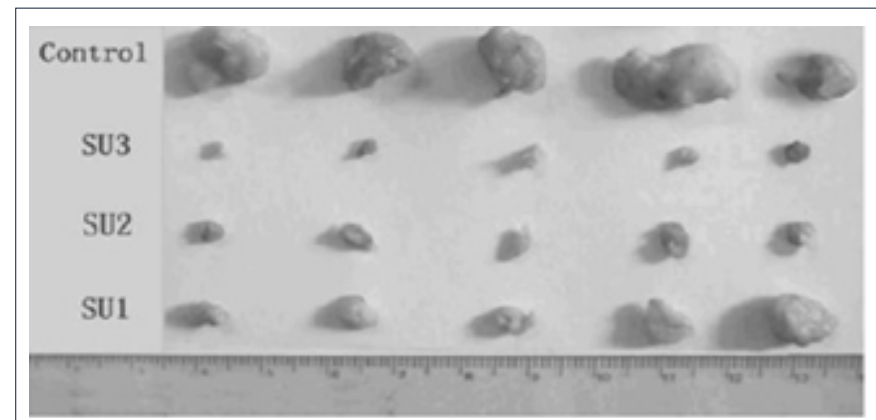

Figure (3): Photograph of mouse S-180 tumours peeled off 15 days after treatment from each group of mice showing the effect of increasing the intensity of ultrasound exposure. Top line - Control sample without ultrasound or Sonnelux 1 administration. Second line ( SU3) - highest ultrasound power used a t $1.2 \mathrm{~W} / \mathrm{cm} 2$, Third (SU2) and Fourth (SU1) lines are decreasing intensity of ultrasound $(0.6 \mathrm{~W} / \mathrm{cm} 2,0.3 \mathrm{~W} / \mathrm{cm} 2)$.

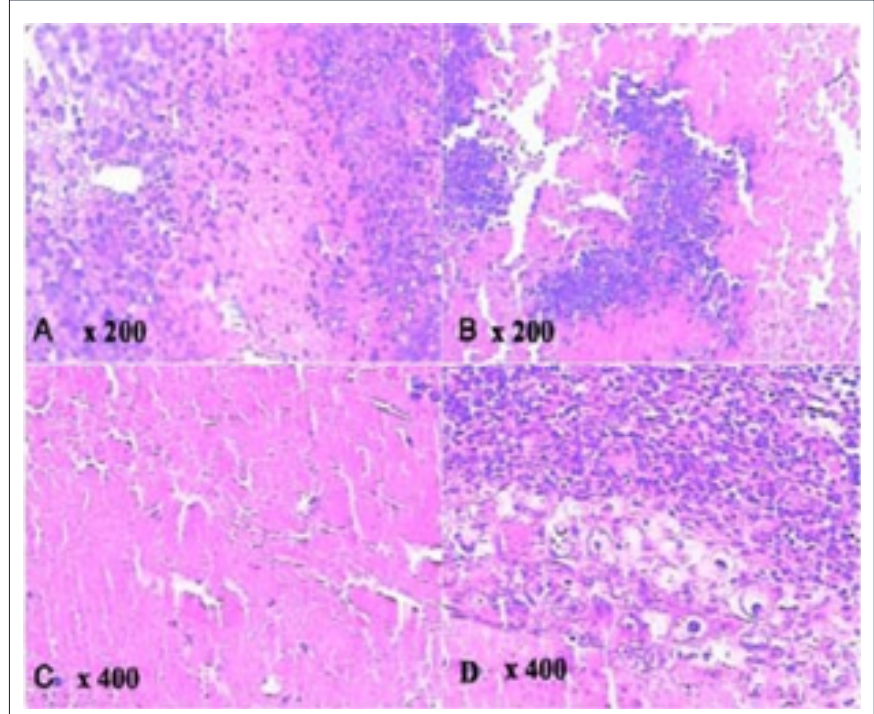

Figure (4): Histological slices of the tumour in a group of mice sonnelux-1 plus ultrasound plus light exposure showing coagulated tumour cell necrosis, inflammatory changes and metamorphic tissue.

B - Slice taken 2 hours after treatment.

C - Slice taken 36 hours after treatment.

D. Slice taken 15 days after treatment

bone barrier was placed between the ultrasound exposure source and the animals under study ${ }^{20}$. Studies have previously supported propagation of ultrasound through bone structure ${ }^{21}$, and this provides further support for the possibility that sufficient ultrasound activation can be a chieved for tumour sites distant or within bone structure.

\section{Method}

\section{SPDT Protocol}

Sonnelux-1 is administered slowly over 2 to 5 hours sublingually to provide sustained low plasma concentration. Our regulators asked us 15 years ago to use sublingual administration, we found this to be entirely satisfactory and have not had to move on to intravenous administration. Forty-eight hours after sublingual administration the patient is exposed to a light bed containing 48 panels of LEDs emitting a combination of visible and infra-red light at the frequencies $660 \mathrm{~nm}$ and $940 \mathrm{~nm}(+/-30 \mathrm{~nm})$. No photosensitivity from normal ambient light, artificial or natural has been noted but as a precaution, patients are advised not to stay in direct sunlight for periods over half an hour for one week following Sonnelux-1 administration. Light bed exposure time varies with shorter exposure duration in cases with larger tumour load. Ultrasound is then applied at $1 \mathrm{~W} / \mathrm{cm} 2$ and a frequency of $1 \mathrm{MHz}$ at sites of known malignant disease, with time titrated on a case by case basis. Light and ultrasound activation is repeated on three consecutive days, and the same process of Sonnelux- 1 administration followed by light and ultrasound exposure 
is repeated after one week to complete a treatment cycle. Ozone Autohaemotherapy is administered immediately before light bed exposure, aiming to increase P02 at the tumour site. Clinically, this has been observed to significantly increase the tumour cytotoxic effect of SPDT. A course of oral Dexamethasone is administered to patients dependent on tumour type, background physical status and total tumour volume. Alongside SPDT protocol, patients underwent supportive nutritional supplementation determined on a case by case basis.

\section{Data Collection}

Details were collated of 17 consecutive patients who received SPDT including hospital diagnosis. All of the patients except one had a Circulating Tumour Cell Test before SPDT and one after. Results have been tabulated for comparison. (Table 1)

Every patient signed an Informed Consent allowing us to use their dated in an anonymous way as we are doing in this publication.

Table 1: Details of patients in the study

\begin{tabular}{|c|c|c|c|c|c|}
\hline & DOB & Type & Diagnosed & Clinical Outcomes & RGCC $^{\mathrm{b}}$ Results \\
\hline 1 & 05/04/1952 & $\begin{array}{c}\text { Abdominal } \\
\text { Carcinosarcoma }\end{array}$ & January 2016 & $\begin{array}{l}\text { Debulking, followed by Colostomy. } \\
\text { Patient refused Chemotherapy. We } \\
\text { carried out SPDT in March 2016. } \\
\text { Expected survival at the time I saw her } \\
\text { on } 24 \text { February } 2016 \text { - her expected } \\
\text { survival was one year - at the time of } \\
\text { writing she is alive and well with no } \\
\text { detectable tumour. }\end{array}$ & $\begin{array}{l}\text { This patient chose not to have a } \\
\text { Circulating Tumour Cell Test }\end{array}$ \\
\hline 2 & 24/10/1951 & Pancreatic Cancer & & $\begin{array}{l}\text { We first saw him on } 21^{\text {st }} \text { July } 2019 \text { with } \\
\text { Pancreatic Cancer. He had SPDT in } \\
\text { September 2019. The second course } \\
\text { in May 2020. Expected survival - } 1 \\
\text { year. He is currently alive and well. }\end{array}$ & $\begin{array}{l}13 / 08 / 2019-3.4 \text { cells per } 7.5 \mathrm{ml} \\
18 / 03 / 2020-3.2 \text { cells per } 7.5 \mathrm{ml} \\
22 / 09 / 2020-3 \text { cells per } 7.5 \mathrm{ml}\end{array}$ \\
\hline 3 & $25 / 11 / 1958$ & Metastatic Colorectal & & $\begin{array}{l}\text { We saw him } 16 \text { July } 2018 \text { - expected } \\
\text { survival one year. We carried out SPDT } \\
\text { in August } 2018 . \\
\text { The patient died in December } 2020 .\end{array}$ & $\begin{array}{l}\text { Circulating tumour cells before } \\
\text { SPDT taken on } 30 / 07 / 2018-7.1 \\
\text { cells per } 7.5 \mathrm{ml} \text {. } \\
\text { Post SPDT on } 05 / 10 / 2018-\text { the } \\
\text { circulating tumour cells were } 6.4 \\
\text { cells per } 7.5 \mathrm{ml} \text {. } \\
09 / 05 / 2019-3 \text { cells per } 7.5 \mathrm{ml} \text {. } \\
25 / 07 / 2019-2.1 \text { cells per } 7.5 \mathrm{ml} \text {. } \\
19 / 11 / 2019 \text { were } 2.2 \text { cells per } \\
7.5 \mathrm{ml} \text {. }\end{array}$ \\
\hline 4 & 05/08/1972 & $\begin{array}{l}\text { Head and Neck } \\
\text { Squamous Cell } \\
\text { Carcinoma. }\end{array}$ & & $\begin{array}{l}\text { We saw the patient on } 23 / 01 / 2019 \text {. } \\
\text { He refused all standard treatments, } \\
\text { expected survival was one year. He is } \\
\text { still alive. }\end{array}$ & $\begin{array}{l}\text { Circulating tumour cell test } \\
\text { carried out pre SPDT on } \\
07 / 02 / 2019 \text { was } 5.6 \text { cells per } \\
7.5 \mathrm{ml} \text {. } \\
\text { He had SPDT and the circulating } \\
\text { tumour cells on } 21 / 05 / 2019 \text { were } \\
5.1 \text { cells per } 7.5 \mathrm{ml} \text {. }\end{array}$ \\
\hline 5 & 20/05/1951 & $\begin{array}{c}\text { Metastatic Colorectal } \\
\text { Cancer. }\end{array}$ & & $\begin{array}{l}\text { We saw him in November } 2017 \text { with } \\
\text { metastatic colorectal cancer. } \\
\text { He is alive and well with no evidence } \\
\text { of disease. Expected survival was one } \\
\text { year. }\end{array}$ & $\begin{array}{l}\text { Circulating tumour cell test } \\
\text { carried out on } 09 / 05 / 2019 \text { was } 3 \\
\text { cells per } 7.5 \mathrm{ml} \text {. } \\
\text { He had SPDT and the circulating } \\
\text { tumour cell test on } 23 / 10 / 2019 \\
\text { was } 2.2 \text { cells per } 7.5 \mathrm{ml} \text {. }\end{array}$ \\
\hline 6 & 19/12/1954 & $\begin{array}{c}\text { Metastatic Breast } \\
\text { Cancer }\end{array}$ & & $\begin{array}{l}\text { We first saw her on } 19 / 05 / 2014 \text { with } \\
\text { metastatic breast cancer. Expected } \\
\text { survival was one year. } \\
\text { She had SPDT in July } 2014 \text {. } \\
\text { She had another round of SPDT in } \\
2016 \text {. } \\
\text { Currently she has stable disease. }\end{array}$ & $\begin{array}{l}\text { Her circulating tumour cells prior } \\
\text { to SPDT were } 10.6 \text { cells per } 7.5 \mathrm{ml} \text {. } \\
\text { Post SPDT they were } 7.3 \text { cells per } \\
7.5 \mathrm{ml} \text {. } \\
\text { She had another round of SPDT in } \\
2016 \text { and her circulating tumour } \\
\text { cells before the SPDT were } 5 \text { cells } \\
\text { per } 7.5 \mathrm{ml} \text {. } \\
\text { Post SPDT her circulating tumour } \\
\text { cells were } 2.5 \text { cells per } 7.5 \mathrm{ml} \text {. }\end{array}$ \\
\hline
\end{tabular}




\begin{tabular}{|c|c|c|c|c|c|}
\hline 7 & 23/03/1950 & $\begin{array}{c}\text { Merkel Cell Cancer on } \\
\text { the Right Cheek }\end{array}$ & & $\begin{array}{l}\text { She had SPDT in 2019. Expected } \\
\text { survival not known. }\end{array}$ & $\begin{array}{l}\text { She had SPDT in } 2019 \text { and her } \\
\text { circulating tumour cells pre SPDT } \\
\text { were } 3.4 \text { cell per } 7.5 \mathrm{ml} \text {. } \\
\text { Post SPDT the circulating tumour } \\
\text { cells were } 2.6 \text { cells per } 7.5 \mathrm{ml} \text {. }\end{array}$ \\
\hline 8 & $18 / 04 / 1948$ & $\begin{array}{c}\text { Gleason } 8 \text { Prostate } \\
\text { Cancer }\end{array}$ & & $\begin{array}{l}\text { His first round of SPDT was in } 2017 . \\
\text { He had another round of } \\
\text { SPDT in March } 2020 .\end{array}$ & $\begin{array}{l}\text { His circulating tumour cells were } 4.4 \\
\text { cells prior to the SPDT in } 2017 \text {. Post } \\
\text { SPDT they were } 2.4 \text {. } \\
\text { Level was } 4.4 \text { in February } 2020 \text {. Post } \\
\text { SPDT the circulating tumour cells } \\
\text { were down to } 3.3 \text { cells per } 7.5 \mathrm{ml} \text {. }\end{array}$ \\
\hline 9 & $18 / 11 / 1945$ & $\begin{array}{c}\text { Gleason } 9 \text { Prostate } \\
\text { Cancer }\end{array}$ & & $\begin{array}{l}\text { We saw this patient with Gleason } \\
8 \text { Prostate Cancer. He refused all } \\
\text { standard treatment. We treated him } \\
\text { with SPDT in } 2017 . \\
\text { Expected survival not known. } \\
\text { Currently he has stable disease. }\end{array}$ & $\begin{array}{l}\text { His circulating tumour cells prior } \\
\text { to SPDT were } 4.7 \text { cells per } 7.5 \mathrm{ml} \text {. } \\
\text { Post SPDT the numbers had come } \\
\text { down to } 2.4 \text { cells per } 7.5 \mathrm{ml} \text {. } \\
\text { Then he had another course of } \\
\text { SPDT following that course of } \\
\text { SPDT the circulating tumour cells } \\
\text { came down to } 3.2 \text { cells per } 7.5 \mathrm{ml} \text {. }\end{array}$ \\
\hline 10. & 19/06/1956 & Breast Cancer & & $\begin{array}{l}\text { She had had standard treatments. We } \\
\text { carried out SPDT in 2019. Expected } \\
\text { survival not known. } \\
\text { She is currently well with no } \\
\text { complaints. }\end{array}$ & $\begin{array}{l}\text { Her circulating tumour cells } \\
\text { before SPDT were } 3.5 \text { cells per } \\
7.5 \mathrm{ml} \text {. } \\
\text { Post SPDT they were } 2.5 \text { cells per } \\
7.5 \mathrm{ml} \text {. }\end{array}$ \\
\hline 11 & $22 / 02 / 1965$ & $\begin{array}{c}\text { Metastatic } \\
\text { Endometrial Clear } \\
\text { Cell Cancer }\end{array}$ & & $\begin{array}{l}\text { We saw this patient with a Metastatic } \\
\text { Endometrial Clear Cell Cancer which } \\
\text { was chemoresistant. Expected survival } \\
\text { was one year. } \\
\text { We carried out SPDT in } 2020 \text { when } \\
\text { we first saw her, her disease was } \\
\text { progressive. } \\
\text { She remains alive. }\end{array}$ & $\begin{array}{l}\text { Her circulating tumour cells } \\
\text { before SPDT were } 6.1 \text { cells per } \\
7.5 \mathrm{ml} \text {. } \\
\text { Post SPDT the circulating tumour } \\
\text { cells were } 5.9 \text { cells per } 7.5 \mathrm{ml} \text {. }\end{array}$ \\
\hline 12 & $22 / 12 / 1936$ & $\begin{array}{c}\text { Metastatic Colorectal } \\
\text { Cancer }\end{array}$ & & $\begin{array}{l}\text { We saw him in July } 2020 \text {. He has } \\
\text { Metastatic Colorectal Cancer. He had } \\
\text { a hemicolectomy and was offered } \\
\text { chemotherapy which he turned down. } \\
\text { We carried out SPDT in September. } \\
\text { Expected survival was one year. } \\
\text { He remains clinically well. }\end{array}$ & $\begin{array}{l}\text { His circulating tumour cells pre } \\
\text { SPDT were } 6 \text { cells per } 7.5 \mathrm{ml} . \\
\text { Post SPDT his circulating tumour } \\
\text { cells were } 3.1 \text { cells per } 7.5 \mathrm{ml} \text {. }\end{array}$ \\
\hline 13 & $22 / 03 / 1970$ & $\begin{array}{l}\text { Clear Cell } \\
\text { Endometrial } \\
\text { Carcinoma }\end{array}$ & 2016 & $\begin{array}{l}\text { This patient had a chemoresistant Clear } \\
\text { Cell Endometrial Carcinoma. } \\
\text { We carried out SPDT on her in 2016. She } \\
\text { also has a diagnosis of Lynch Syndrome. } \\
\text { Expected survival was two years. } \\
\text { She is currently clear of any scan } \\
\text { evidence of cancer. }\end{array}$ & $\begin{array}{l}\text { Her circulating tumour cells pre } \\
\text { SPDT were } 7.4 \text { cells per } 7.5 \mathrm{ml} \text {. } \\
\text { Post SPDT they had gone down to } \\
4.1 \text { cells per } 7.5 \mathrm{ml} \text {. }\end{array}$ \\
\hline 14 & 29/05/1964 & GIST Tumour & & $\begin{array}{l}\text { This patient presented to us with } \\
\text { a GIST Tumour in March } 2019 \text {. He } \\
\text { turned down chemotherapy. } \\
\text { This patient has been lost to follow up. }\end{array}$ & $\begin{array}{l}\text { His pre SPDT circulating tumour } \\
\text { cell test showed } 6.2 \text { cells per } \\
7.5 \mathrm{ml} \text {. } \\
\text { Following SPDT this went down } \\
\text { to } 5.8 \text { cells per } 7.5 \mathrm{ml} \text {. }\end{array}$ \\
\hline 15. & 23/06/1967 & Breast Cancer & & $\begin{array}{l}\text { This patient has Breast Cancer. } \\
\text { Expected survival unknown. This } \\
\text { patient is alive and well at the time of } \\
\text { writing. }\end{array}$ & $\begin{array}{l}\text { Her pre SPDT circulating tumour } \\
\text { cell test was } 3.5 \text { cells per } 7.5 \mathrm{ml} \text {. } \\
\text { Following SPDT her number of } \\
\text { circulating tumour cells was } 2.6 \\
\text { cells per } 7.5 \mathrm{ml} \text {. }\end{array}$ \\
\hline 16. & 07/02/1954 & $\begin{array}{c}\text { Metastatic Breast } \\
\text { Cancer }\end{array}$ & & $\begin{array}{l}\text { This patient turned down } \\
\text { chemotherapy and radiotherapy, we } \\
\text { carried out SPDT. } \\
\text { This patient has been lost to follow up. }\end{array}$ & $\begin{array}{l}\text { Her circulating tumour cell test } \\
\text { before SPDT were } 8.1 \text { cells per } \\
7.5 \mathrm{ml} \text {. } \\
\text { Post SPDT they went down to } 5.6 \\
\text { cells per } 7.5 \mathrm{ml} \text {. }\end{array}$ \\
\hline
\end{tabular}




\begin{tabular}{|l|l|l|l|l|l|}
\hline 17. & $17 / 06 / 1944$ & $\begin{array}{c}\text { Metastatic Colorectal } \\
\text { Cancer }\end{array}$ & 2019 & $\begin{array}{l}\text { Standard treatments were carried out. } \\
\text { Expected survival one year. } \\
\text { We carried out SPDT on him in 2019 Cells were 3.5 cells per 7.5ml. } \\
\text { following his Hemicolectomy. } \\
\text { He remains alive and well. }\end{array}$ \\
\hline $\begin{array}{l}\text { Post SPDT the Circulating Tumour } \\
\text { Cells were 2.5 cells per 7.5ml. }\end{array}$
\end{tabular}

a SPDT - Sono and Photodynamic Therapy

${ }^{b}$ R.G.C.C. International GmbH, Zug, Switzerland

Source: The Dove Clinic, Twyford, Winchester, Hants. SO21 1RG

\section{Results}

All patient data is anonymously displayed in Table 1 . Patient data has only been presented when a predicted median survival was known. Of those patients still alive, only those who have exceeded the predicted survival data are relevant, many patients however, are alive at the time of writing, therefore the survival benefit is unknown at the time of writing. All cases showed a reduction in Circulating Tumour Cells following SPDT except for Case 1, who refused the test.

PDT will destroy tumour down to $2 \mathrm{~cm}$, SDT will deal with deep-seated tumour. Therefore, combining the two deals with the tumour load and the distribution of the tumour in our patients. In the past we have tried using Light Bed treatment alone, this has some clinical benefit but this is maximised by adding in SDT.

\section{Discussion}

SPDT using Sonnelux has shown significant promise over a fifteen-year period as a safe and well tolerated noninvasive treatment, even in advanced metastatic cancer Extension and median survival times are here reported, with patients of various cancer diagnosis.

Second and subsequent courses of Sono and Photodynamic Therapy may have further benefit in reducing tumour mass and inhibiting tumour cell growth without the total dose limitations of radiotherapy. There is a trend in the cases reported here, that further treatment reduced significantly on previous circulating tumour cell numbers.

It is suggested that unlike immunologically silent genotoxic damage produced by radiotherapy and chemotherapy, photooxidative cytotoxic lesions generated by Sono and Photodynamic Therapy are extra nuclear and result in a rapid cell death as it alerts the host's innate immune system ${ }^{22}$. Neutrophil mobilisation and innate immune cell activation are responsible for the development of tumour antigen-specific adaptive immune cascades that contribute to the eradication of Sono and Photodynamic Therapy treated cancers. This is further supported by in vitro studies which establish the tumour cells treated by PDT can be used for generating potent vaccines against cancers of the same origin ${ }^{23}$.

Tumour hypoxia has been found to a characteristic feature in many solid tumours ${ }^{24}$. It has been demonstrated the tumour hypoxia, either pre-existing or as a result of oxygen depletion during photodynamic therapy can significantly reduce the effectiveness of PDT-induced cell killing.

This study reports that when Sono and Photodynamic Therapy is combined with hyperoxygenation the hypoxic condition could be improved and the cell killing rate at various time points after Sono and Photodynamic Therapy could be significantly enhanced ${ }^{25}$.

Previously, it has been shown in arteriopathic patients that Ozone Autohaemotherapy has a therapeutic potential by increasing oxygen delivery in hypoxic tissue ${ }^{26}$.

Clinically, it appears that greater tumour response is Sono and Photodynamic Therapy following Ozone Autohaemotherapy. This would seem to relate to an increase on singlet oxygen levels in the tumour microenvironment.

\section{Conclusion}

The limitations of this study are that it is observational, and therefore this supports the suggestion for further studies using this particular approach. Sono and Photodynamic Therapy warrants further investigations, a non-invasive, well tolerated, clinically effective targeted cancer treatment capable of tumour cell necrosis and both superficial in deep malignant sites. All of the patients reported here showed a drop pre and post treatment with SPDT of their circulating tumour cells. This is indeed a remarkable finding.

\section{Conflicts of Interest}

There are no conflicts of interest.

\section{References}

1. Kenyon J N, Fuller RJ, Lewis TJ. Activated Cancer Therapy Using Light and Ultrasound - A Case Series of Sonodynamic Photodynamic Therapy in 115 Patients over a 4 Year Period Current Drug Therapy, 2009, 4, 179-193

2. Kenyon J N, Fuller RJ. Outcome Measures Following Sonodynamic Photodynamic Therapy-A Case Series Current Drug Therapy, February 6(1) 2011.

3. Papasotiriou I, Chatziioannou M, Pessiou $\mathrm{K}$ et al. Detection of circulating tumor cells in patients with breast, prostate, pancreatic, colon and melanoma cancer: A blinded comparative study using healthy donors. J Cancer Ther 6: 543-553, 2015.

4. Sonodynamic and Photodynamic Therapy in Advanced Breast 
Carcinoma: A report of three cases. Xiahuai Wang MD, Weimim ZhangMD, Zhiyong Xu MD, Yifan Lu PhDo, Doug Mitchell PhD and Ralph W Moss PhD. Department of Oncology, Liu Hua Hospital, Guangzhou, China

5. Primary clinical use of Sonodynamic therapy (SDT) for advanced breast cancer. (External link) American Society of Clinical Oncology 2008 Breast Cancer Symposium, T.J. Lewis PhD, X Wang MD.

6. Murphy 1,2. Brian Meade 3, Avni Sali 3. Geelong Private, St John of God and Colac Hospitals1, skills Laboratory RACS. Melbourne 2, National Institute of Integrative Medicine Melbourne3.Urological Society of Australia and New Zealand No. 089 April 2013 Prostate Cancer Treated by Sonodynamic and Photodynamic Therapy (SPDT, NGPDT).Donald

7. Sibata C H, Colussi V C, Oleinick N L, Kinsella T J. Photodynamic therapy in oncology. Expert Opin Pharmacother 2001; 2( 6): 917- 27.

8. Jensen J. A model for the propagation and scattering of ultrasound in tissue. J Acoust Soc Am 1991; 182-90

9. Ziskin MC. Fundamental physics of ultrasound and its propagation in tissue. Radiographics 1993; 13: 705-9.

10. Bailey M R, Khokhlova V A, Sapozhnikov O A, Kargl S G, Crum LA. Physical mechanisms of the therapeutic effect of ultrasound. Acoust Phys 2003; 49(4): 369-88

11. Kondo T, Kano E. Effect of free radicals induced by ultrasonic cavitation on cell killing. Int J Radiat Biol 1988; 54(3): 475-86.

12. Huang Z. A review of progress in clinical photodynamic. Ther Technol Cancer Res Treat 2005; 4(3): 283-93.

13. Loreto B, Feril LB, Kondo T. biological effects of low intensity ultrasound: The mechanism involved, and its implications on therapy and on biosafety of ultrasound. J Radiat Res 2004; 45: 479-89.

14. Kremkau FW, Kaufmann J S, Walker MM, Burch PG, Spurr C L. Ultrasonic enhancement of nitrogen mustard cytotoxicity in mouse leukaemia. Cancer 1976; 37: 1643-7

15. Harrison GH, Balcer-Kubiczec EK, Eddy HA. Potentiation of chemotherapy by low-level ultrasound. Int J Rad Biol 1991; 59(6): 1453-66
16. Yumita N, Nishigaki R, Umemara K, Umemara S. Hematoporphyrin as a sensetizer of cell-damaging effect of ultrasound. Jpm J Cancer Res 1989;80(3):219-22

17. Rosenthal I, Sostaric J, Riesz P. Sonodynamic Therapy-a review of the synergistic effects of drugs and ultrasound. Ultrason Sonechem 2004; $11: 349-63$

18. Wakako H, Hidemi H, Loreto B, Feril J, Nobuki K, Takashi K. Comparison between sonodynamic effect and photodynamic effect with photosensitizers on free radical formation and cell killing. Ultrason Sonochem 2006; 13(6): 535-42

19. Wang P, Wang XB, Liu QH, Tang W, Li T. Enhancement of ultrasonically induced cytotoxic effect by hematoporphyrin in vitro. Chemotherapy 2008; 54: 364- 71.

20. Wang $X$, Lewis T, Mitchell D. The tumoricidal effect of sonodynamic therapy (SDT) on S -180 sarcoma in mice. Integr Cancer Ther 2008; 7: 96-102.

21. White P, Hynynen K, Clement G. Longitudinal and shear mode ultrasound propagation in human skull bone. Proceedings of the 5th meeting of the International Society on Therapeutic Ultrasound 2005; $251-5$

22. Castano A P, Mroz P, Hamblin MR. Photodynamic therapy and antitumour immunity. Nat Rev Cancer 2006; 38:500-8

23. Hoogsteen IJ, Marres HA, van der Kogel AJ, Kaanders JH. The hypoxic tumour microenvironment patient selection and hypoxi a modifying treatments. Clin Oncol (R Coll Radiol) 2007; 19(6): 385-96

24. Korbelix M, Stott B, Sun J. Photodynamic therapy-generated vaccines: relevance of tumour cell death expression. Brit J Cancer 2007; 97: 1381-7

25. Juang A, Chen $Q$ Shakil A, et al. Hyperoxygenation enhances the tumor cell killing of photofrin-mediated photodynamic therapy. Photochem Photobiol 2003; 78(5):496-502

26. Bocci C, Larini A, Micheli V. Restoration of normoxia by ozone therapy may control neoplastic growth: a review and a working hypothesis. J Altern Complement Med 2005; 11(2): 257-65 